\title{
Leading Entrepreneurship Education-Based Primary Schools
}

\author{
Suryaman \\ Universitas PGRI Adi Buana Surabaya, Indonesia \\ mama_suryaman58@yahoo.co.id
}

\author{
Hari Karyono \\ Universitas PGRI Adi Buana Surabaya, Indonesia \\ harikaryana@yahoo.com
}

\begin{abstract}
This research described how to design a leading school based on entrepreneurship. Leading schools are the hope of the community who care about education. In the global era, graduates of educational institutions are also expected to succeed in facing the challenges of the era. The problem was how to describe a leading school based on entrepreneurship. The research employed a descriptive qualitative method. The research site was at a primary school, namely SD Pembangunan Jaya 2 Sidoarjo. The results showed that the indicators developed in the curriculum of entrepreneurship included the values of: creative, innovative, independent, value added, dare to risk, and able to see opportunities. Based on the results of research it can be concluded that the leading school should have a supporting factor, based on entrepreneurship education.Based on the results of research it is suggested that at the time of implementation of learning activities teachers should carefully consider the learning strategies that would be implemented in entrepreneurship education.
\end{abstract}

Keywords: design, leading school, enterpreneur

\section{INTRODUCTION}

Someone who has an entrepreneurial spirit is those whose personality has internalized entrepreneurial values, i.e. personality that has creative action as value, fond of trying, tough in various challenges, confident, have self-determination, or locus of control, be able to manage risks, a change is viewed as an opportunity, tolerance of various choices, initiative and possessing need for achievement, perfectionism, broad-mindedness, thinking that time is valuable and strongly motivated, and that character has all been internalized as values believed to be true (Kuratko, 2003).

In fact the government has promoted entrepreneurship, but the efforts have not had a significant impact (Mulyani, 2011). Presidential Instruction No. 4 of 1995 on the National Movement of Socializing and Culturing Entrepreneurship, mandated to the entire community and the nation of Indonesia to develop entrepreneurial programs. Entrepreneurship is one's passion, attitude, behavior and abilities in handling business and/or activities that lead to the searching, creating, applying of new ways of working, technology and products by improving efficiency in order to provide better service and/or gain more considerable benefits.

Indonesia's high purchasing power, abundant demographic bonuses and large markets are Indonesia's opportunities to grow and prosper. This makes entrepreneurship an appropriate and promising choice in increasing revenue and contributing a great value to the growth of the country's economy. Demographic bonuses will not be demographic bills if this potential is developed and put to good use (Setiowati, 2015).

According to Asnawi (2012), a State will achieve prosperity if there are not less than $2 \%$ of the nation/state population to become entrepreneurs. Singapore has only $7 \%$ and the United States $11 \%$. While in Indonesia it is estimated to be around 400 thousands or only $0.18 \%$. Therefore, it should continue to be driven by young entrepreneurs who are expected to contribute to the prosperity of the State.

In essence, entrepreneurship education has the following values: honest, disciplined, hard work, creative, innovative, independent, responsibility, cooperation, leadership, unyielding, dare to risk, commitment, realistic, curiosity, communicative, powerful motivation for success, and action-oriented. Wiyatno (2009) has suggested that entrepreneurs as someone who dares to take risks, smell business opportunities, and able to utilize resources effectively and efficiently to gain profit.Therefore, education is an instrument that is considered most effective to instill entrepreneurial values. This is in accordance with the statement of Kourilsky \& Walstad (1998) suggesting that the influence of entrepreneurship education has been considered as an important factor to cultivate and develop entrepreneurial passion, soul and entrepreneurial behavior among the younger generation.

Entrepreneurship is often seen as a way of life (Gibb, 1998). Much of the literature on entrepreneurship focuses on the person, characteristic and quality of an entrepreneur. The development of 'spirit' is often seen as important and as the main criterion for deciding who chooses entrepreneurship and becomes successful in that field (Tolentino, 1998). Although Mintzberg (1990) notes that the literature on the characteristics and quality of entrepreneurs is hardly based on empirical evidence, there is still much research. Sudrajat (2011) argued that until now the concept of entrepreneurship is still growing. As also stated by Asnawi (2012) that entrepreneurs always look for change, respond, and use it as an opportunity.

Schools as educational institutions should not only focus on the development of children's intellectual intelligence, but also focus on developing a child's character or personality in line with the national education goals. Damsar (2011) argues that schools are one of the socialization agencies that play a role in shaping knowledge, attitudes, values, norms, essential behaviors and hopes of being able to participate effectively in society. Through education that takes place in schools, it is expected to be born generations who have strong character to be able to compete in the era of globalization.

Elementary school is a schooling time for children of 7-12 years old. It relates to the development 
of cognitive children at the age of 7-12 years. According to Barnawi \& Arifin (2012) primary school is the most basic formal education level and it is deemed appropriate to start applying entrepreneurship education. Through the planting of characters from the most basic level of education it is expected to give a big influence on the development of entrepreneurship education. This is carried out as an effort to promote entrepreneurship and the process of internalization and actualization of entrepreneurial character values in the realm of education.

However, entrepreneurship education, especially at the primary school level, has not been widely applied. There are few primary schools that implement entrepreneurship education. Only a few large private schools, while public schools have not yet implemented. Some of the factors that cause schools not to implement entrepreneurship education are the limited knowledge of educators related to entrepreneurship. School principals and teachers still have not gained knowledge or training on the application of entrepreneurship education.

SD Pembangunan Jaya 2 Sidoarjo is a multicultural public school, always instilling religious values to students in accordance with their respective religions. Through the process of social interaction at school, they learn to respect other religions, so as to become a tolerant person. Teachers of SD Pembangunan Jaya 2 Sidoarjo are professional, creative, innovative, and highly dedicated and committed to improving students' academic and non academic achievement, and supported by competent teachers in their fields with bachelor's and master's degrees.

In accordance with the motto "learning is fun" then the implementation of teaching and learning activities is carried out with the moving class system and facilities that support learning, such as laboratory, multimedia room, school garden, religious room, computer room, and multi purpose hall (SD Pembangunan Jaya 2 Sidoarjo, 2016). Inspired by the pioneering principles of the founders in the context of entrepreneurship education, SD Pembangunan Jaya 2 Sidoarjo has intention to produce graduates who are to continue to the next level of education and able to answer the nation's challenges to the superiority of Indonesian human resources.

Meanwhile, one of the solutions offered by the government to reduce the unemployment rate is to create employment opportunities with entrepreneur model (Asnawi, 2012). Education education is important, the solution is none other than to recognize the entrepreneur from an early age (Publisher Erlangga, 2011). Since learners are schooling in elementary schools, the idea of SD Pembangunan Jaya 2 Sidoarjo in entrepreneurship education needs to be appreciated as a concrete step to prepare learners for entrepreneurship from an early age.

Basically, education is the gateway of the next generation of the nation to form a superior person, both individually and in groups. Entrepreneurship as an alternative solution in developing all the potentials of the nation can now be taught through learning in schools. According to Ciputra (2009), the minimum number of a nation's population is two to be capable of breaking down and promoting economic progress.

\section{METHODS}

This is a research with qualitative approach. The type of research used was descriptive-qualitative. The researchers used the qualitative research to reveal entrepreneurship education in SD Pembangunan Jaya 2 Sidoarjo. The research object was the entrepreneurship education implemented in SD Pembangunan Jaya 2 Sidoarjo. The research subjects covered the source data to be asked for information. The informant of this research was the principal, teacher of curriculum section and teacher who taught entrepreneurship education. Data analysis was carried out through continuous analysis to include collecting, analysis and interpretation which were applied at the same time as stated by Bogdan \& Biklen (1998).

\section{RESULTS AND DISCUSSION}

SD Pembangunan Jaya 2 Sidoarjo which is located at Vancouver Park Block J 1/1, Puri Surya Jaya Housing, Gedangan Sidoarjo, is one of the leading schools that implements entrepreneurship education. The entrepreneurship education in this school is inspired by the founders of the school. Furthermore, this school implements entrepreneurship education integrated into the lessons.

The results showed that entrepreneurship education in SD Pembangunan Jaya 2 Sidoarjo was implemented in line with the principles of pioneering by the founders. From the academic side in this school there were two curriculums namely the national curriculum and the leading curriculum. The main curriculum in SD Pembangunan Jaya 2 Sidoarjo included the leading or superior programs consisting of: extracurricular, club, religious activities, Futsal East Java Governor Cup, Adiwiyata School, SPJ Leading Curriculum, Maths and Science Sidoarjo Regent Trophy, Global Entrepreneurship Week, Multicultural School; whereas the core competences/content competencies developed by SD Pembangunan Jaya 2 Sidoarjo are: (1) science workshop; (2) entrepreneurship; (3) liberal arts; and (4) sustainable eco development. The principles of curriculum development that are applied based on the following principles: (1) center on the potential, development, needs and interests of learners and the environment; (2) diverse and integrated; (3) responsive to the development of science, technology and art; (4) relevant to the needs of life; (5) comprehensive and sustainable; (6) lifelong learning; and (7) balanced between national and regional interests.

According to Rina Sugiarti, a student leader and activity coordinator, has stated that as a national private school, SD Pembangunan Jaya 2 Sidoarjo has a leading curriculum that is not owned by other schools, namely entrepreneurship. With entrepreneurship education, it is expected that the graduates of SD Jaya 2 Sidoarjo have creativity, innovation, independence and courage to take measurable risks, to continue to the next level of 
education and able to answer the nation's challenge to Indonesia's human resources excellence.

The main goal of entrepreneurial learning is to change the mind-set, so that the entrepreneurial spirit can be conditioned (by design). By this entrepreneurial learning, the students are encouraged to seek and create valuable opportunities, so innovators find solutions for people and people who dare to take risks which are measurable.

One example of the implementation of entrepreneurship education in SD Pembangunan Jaya 2 Sidoarjo is by conducting a screen printing workshop. According to Donny Hermawan (Marketing Promotion Event for Eprint and Epro from PT Sinar Asia Perkasa), the main objective of activities is to support entrepreneurship lessons, enlarge insight, and knowledge of students about business world as well as digital printing. Through this activity, the students can see business opportunities that are cheap and easy to do. In addition, through screen printing workshops through digital printing, the students will be accustomed to always follow the development of existing technology.

In this learning activity, a few days before the students had been informed about the workshop. Therefore, they were asked to prepare plain white shirt as the main media, markers for drawing on paper screen printing. This screen printing workshop was attended by the sixth grade students to learn rakblon with digital printing media to equip students to be more independent, intelligent, critical, rational, and creative.

The leading curriculum learning activities in SD Pembangunan Jaya 2 Sidoarjo are arranged as follows: (1) Implementation in grades $1-5$; (2) Semester $1=$ The first 4 months are used for the national curriculum and the following 2 months for the SPJ's outstanding curriculum; and (3) Semester 2 = the first 2 months for the SPJ's leading curriculum and the next 4 months of the national curriculum. The learning outcomes developed in the entrepreneurship curriculum at SD Pembangunan Jaya 2 Sidoarjo are: (1) creative; (2) innovative; (3) independent; (4) value added; (5) risktaking; and (6) able to see opportunities.

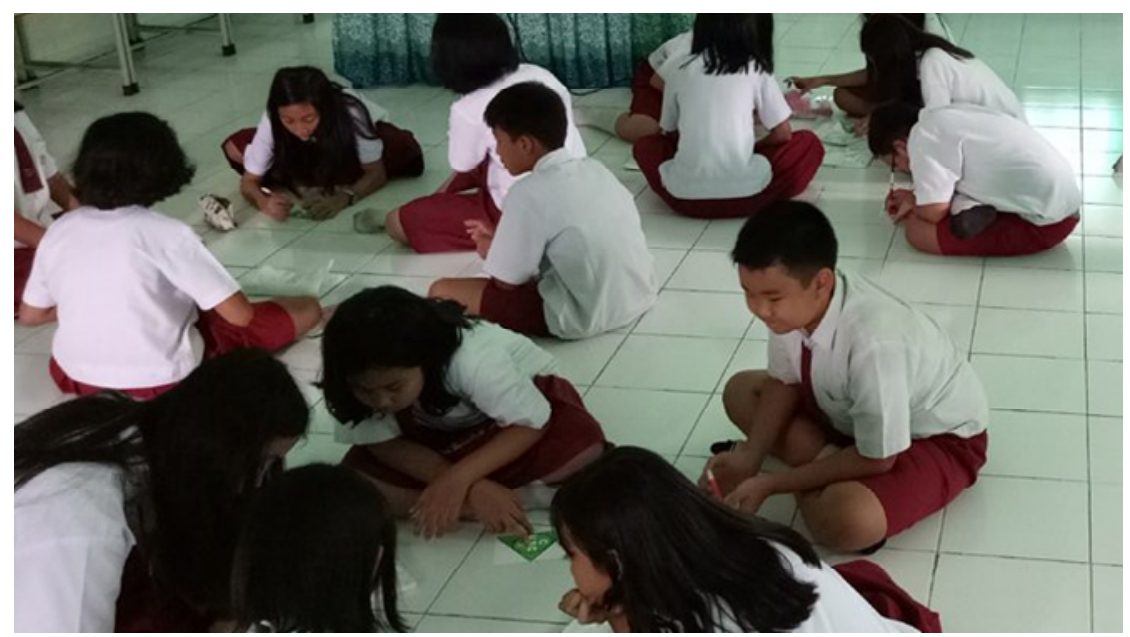

Figure 1

Grade 6-Students of SD Pembangunan Jaya 2 Sidoarjo Learning Entrepreneurial Screen Printing Techniques

SD Pembangunan Jaya 2 Sidoarjo as one of the leading primary schools in Sidoarjo has a leading Curriculum, in addition to the National Curriculum set by the government (Ministry of Education and Culture). Elementary School is a school time for children of 7-12 years old. The cognitive development of children aged 7-12 years is a concrete operational stage. According to Poerwati (2013) the mindset of elementary students is more pronounced and willing to accept changes from outside, so as to adapt to the environment. Thus it will be easy for educators to provide motivation and mindset about effective entrepreneurship.

The values developed should be directed to the development of values from the characteristics of an entrepreneur. According to entrepreneurial experts, there are many entrepreneurial values that are considered the most basic and appropriate to the level of development of learners as much as 17 grades that should be owned by learners and other school residents. Implementation of core values of entrepreneurship is not directly implemented simultaneously by the education unit, but carried out through stages. This does not mean to limit the planting of values (internalization). That is not done uniformly to all schools, but every level of education units can internalize the values of other entrepreneurs independently as necessary. Implementation of the values of entrepreneurship, namely: (1) self; (2) creative; (3) take risks with consideration; (4) action-oriented; (5) leadership; (6) hard worker; (7) honest; (8 ) discipline; (9) innovative; (10) responsibility; (11) cooperation; (12) abstinence; (13) commitment; (14) realistic; (15) curiosity; (16) communicative; and (17) strong motivation for success (Kemendiknas, 2010).

The main goal of entrepreneurial learning in SD Pembangunan Jaya 2 Sidoarjo is to change the mindset, so that entrepreneurial spirit can be conditioned. By this entrepreneurial learning, students are 
encouraged to seek and create valuable opportunities as innovators find solutions for society and the figure who dare to take risks measurably. In the learning activities of entrepreneurship education in schools, teachers have a very strategic role. Therefore, the improvement of teachers' ability to internalize entrepreneurial values is important (Christiani \& Sriwijayanti, 2016).

In relation to the influence of entrepreneurship education as described by Kourilsky \& Walstad (1998) above, some previous studies have shown that the entrepreneurship desire of learners is a source for the birth of future entrepreneurs (Gorman, et. al., 1997; Kourilsky \& Walstad, 1998). In addition, according to Arianto (2011) entrepreneurship is an alternative solution that has a multiplier effect, which can solve problems.

The basic question is why it should be at the elementary school level. As it is known that the development of social aspects begins during childhood (ages 3-5 years) when children enjoy playing with peers. Relationships with peers are ongoing and rather rapidly occur in elementary school. According to Armstrong (2006) most of the developmental development of elementary school age is full participation in the social world. Because able to think in reverse, children at this age so able to engage in mutual relationships and social relationships. For example, when playing, children can spend time arguing about rules of fair play and rules, or doing processes when the process is not working. In this case it can be said that social development can be interpreted as a learning process of children to adapt to group norms.

\section{CONCLUSION}

From the previous description, the following conclusions can be drawn: (1) the implementation of entrepreneurship education in SD Pembangunan Jaya 2 Sidoarjo is inspired by the founders of this school; (2) in general, students' perceptions of entrepreneurial learning by teachers are relatively adequate, in the case of presentation and systematics of entrepreneurship materials need further refinement, so that students are able to absorb well the entrepreneurial materials; (3) the indicators of learning outcomes developed in the curriculum of excellence entrepreneurship include the following elements: (a) creative, (b) innovative, (c) self-sufficient, (d) value added, (e) dare to take risks, and (f) be able to see opportunities; and (4) entrepreneurship learning in elementary school, as well as able to develop physical, social, basic numeracy, reading, writing expected to develop student independence.

Based on the above conclusions, the suggestions can be put forward as follows: (1) the government needs to issue a policy in the field of education on the importance of entrepreneurship subjects taught from an early age; (2) educational institutions should be more concrete in preparing courses of learning activities which can really encourage the growth and development of entrepreneurial spirit from elementary school to college; (3) entrepreneurial values shoud be integrated into all subjects; (4) at the time of implementation of teacher learning activities should carefully consider the learning strategy to be used in entrepreneurship education; and (5) the results of entrepreneurship education assessment should be included in the report of student learning outcomes, so that the students' development can be monitored and reviewed.

\section{REFERENCES}

[1] Amstrong, T. 2006. The Best School (Mendidik Siswa Menjadi Insan Cendekia Seutuhnya). Bandung: PT Mizan Pustaka.

[2] Asnawi, N. 2012. Wirausaha sebagai Solusi Pengangguran Terdidik di Indonesia. Malang: Fakultas Ekonomi, Universitas Islam Negeri Maulana Malik Ibrahim.

[3] Barnawi, \& Arifin, M. 2012. School Preneurship Membangkitkan Jiwa dan Sikap Kewirausahaan Siswa. Yogyakarta: Ar-Ruzz Media.

[4] Bogdan, R. C., \& Biklen, S. K. 1998. Qualitative Research in Education: an Introduction to Theory and Methods. New York: McGraw Hill.

[5] Christiani, E. D., \& Sriwijayanti, R. P. 2016. Penerapan Pendidikan Kewirausahaan di Sekolah Dasar dalam Upaya Menghadapi Masyarakat Ekonomi ASEAN. Proceeding National Seminar Hasil Penelitian Pendidikan dan Pembelajaran SKTIP PGRI Jombang, Jawa Timur, Indonesia, 23-24 April.

[6] Ciputra. 2009. Ciputra Quantum Leap (Entrepreneurship Mengubah Masa Depan Bangsa dan Masa Depan Anda). Jakarta: PT Elex Media Komputindo.

[7] Damsar. 2011. Pengantar Sosiologi Pendidikan. Jakarta: Kencana.

[8] Gibb, A. 1998. Entrepreneurial Core Capacities, Competitiveness and Management Development in the $21^{\text {st }}$ Century. Durham: DUBS.

[9] Gorman, G., Hanlon, D., \& King, W. 1977. Entrepreneurship Education: the Australian Perspective for the Nineties. Journal of Small Business Education, 9, 1-14.

[10] Instruksi Presiden Republik Indonesia Nomor 4 Tahun 1995 tentang Gerakan Nasional Memasyarakatkan dan Membudayakan Kewirausahaan. $2000 . \quad$ Jakarta: Ministry of National Education.

[11] Kementerian Pendidikan Nasional. 2010. Pengembangan Pendidikan Kewirausahaan - Bahan Pelatihan Penguatan Metodologi Pembelajaran Berdasarkan Nilai-Nilai Budaya untuk Membentuk Daya Saing dan Karakter Bangsa. Jakarta: Badan Penelitian dan Pengembangan Pusat Kurikulum.

[12] Kourilsky, M. L., \& Walstad, W. B. 1998. Entrepreneurship and Female Youth: Knowledge, Attitude, Gender Differences, and Educational Practices. Journal of Business Venturing, 13(1), 7788.

[13] Kuratko, D. F. 2003. Enterpreneurship Education: Emergin Trends and Challenger for The 21 Centure. The Entrepreneurship Program.

[14] Mintzberg, H. 1990. Strategy Formation: Schools of Thought. In Frederickson, J. W., (Ed.)., Perspectives on Strategic Management. New York: Harper \& Row.

[15] Mulyani, E. 2011. Model Pendidikan Kewirausahaan di Pendidikan Dasar dan Menengah. Jurnal Ekonomi \& Pendidikan, 8(1).

[16] Penerbit Erlangga. 2011. Proposal Seminar/Workshop Kewirausahaan untuk Siswa SMA/SMK - Siswa Juga Bisa Jadi Pengusaha. Jakarta: Penerbit Erlangga. 
[17] Poerwati, E. L. 2013. Panduan Memahami Kurikulum 2013. Jakarta: Prestasi Pustaka.

[18] SD Pembangunan Jaya 2 Sidoarjo. 2016. Kurikulum Unggulan SD Pembangunan Jaya 2 Sidoarjo. Retrieved December 1, 2016, from http://sd. sidoarjo.jayaschool.org/index.php?stkid=44.

[19] Setiowati, G. R. 2013. Menumbuhkan Wirausahawan Muda Indonesia dengan Pendidikan Wirausaha Terintegratif. Retrieved December 1, 2016, from http://www.kompasiana.com/gilangramadani/menumbu hkan-wirausahawan-muda-indonesia-denganpendidikan-wirausahaterintegratif_55283daff17e619f2f8b45b7.

[20] Tolentino, A. 1998. Training and Development of Entrepreneurs-Managers of Small Enterprices: Pointers and Lessons Learned. Geneva: International Labour Organization.

[21] Wiyatno, S. 2009. Pengantar Entrepreneurship. Jakarta: Gramedia. 